\title{
A Literature Review on the Location Determinants of FDI
}

\author{
Yang Feng ${ }^{1}, \&$ Yang Wang ${ }^{1}$ \\ ${ }^{1}$ Central University of Finance and Economics, School of Economics, Beijing 100081, China \\ Correspondence: Yang Feng, Central University of Finance and Economics, School of Economics, Beijing \\ 100081, China
}

Received: March 8, 2021

doi:10.5539/ibr.v14n4p126

\author{
Accepted: March 29, 2021 \\ Online Published: March 29, 2021 \\ URL: https://doi.org/10.5539/ibr.v14n4p126
}

\begin{abstract}
Foreign direct investment (FDI) is an important force to promote economic growth and social development in both developed and developing countries, while the distribution of FDI in the world and within countries is extremely uneven. This paper systematically summarizes the main determinants that affect the location choice of FDI in recent theoretical and empirical studies, including institution and investment environment, trade cost and industrial agglomeration, market size and natural resource, cultural distance and social network. Based on the work of this paper, it is helpful to better understand the location preference of multinational enterprises (MNEs) in FDI activities, and provide a reference basis for the host country to attract investment and promote economic growth.
\end{abstract}

Keywords: FDI, location determinant, multinational enterprise

\section{Introduction}

As we know, FDI has a positive effect on the economic growth, social development and technological progress of the host country from the experience of both developed and developing countries. However, for the global distribution of FDI, the top 10 countries have attracted 70\% or even more of FDI inflows in the long time. For instance, figure 1 lists the share of global FDI inflows for six largest economies in the world. At the same time, the location distribution of FDI within an economy is usually uneven. For instance, as shown in figure 2, most of the FDI inflows is concentrated in the eastern coastal areas of China at 2000, and it is rare in the western region, after China joins in the WTO at 2001, the situation changes slightly. It shows that multinational enterprises have strong strategic methods for the location destination when making FDI decisions.

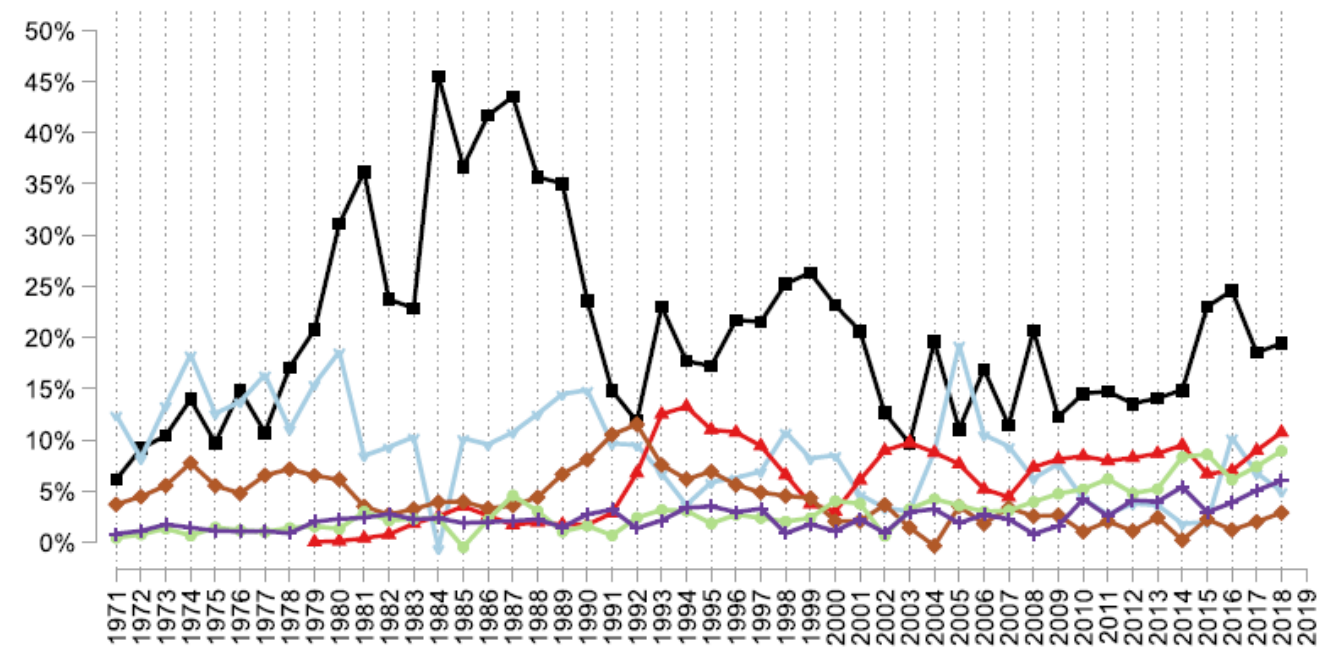

Figure 1. The share of world's FDI inflows for six economies

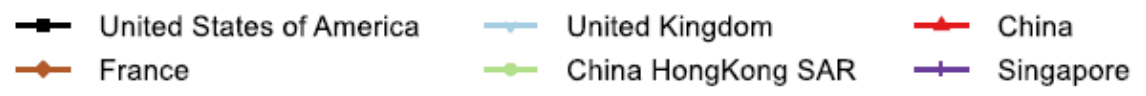

Source: United Nations Conference of Trade and Development 


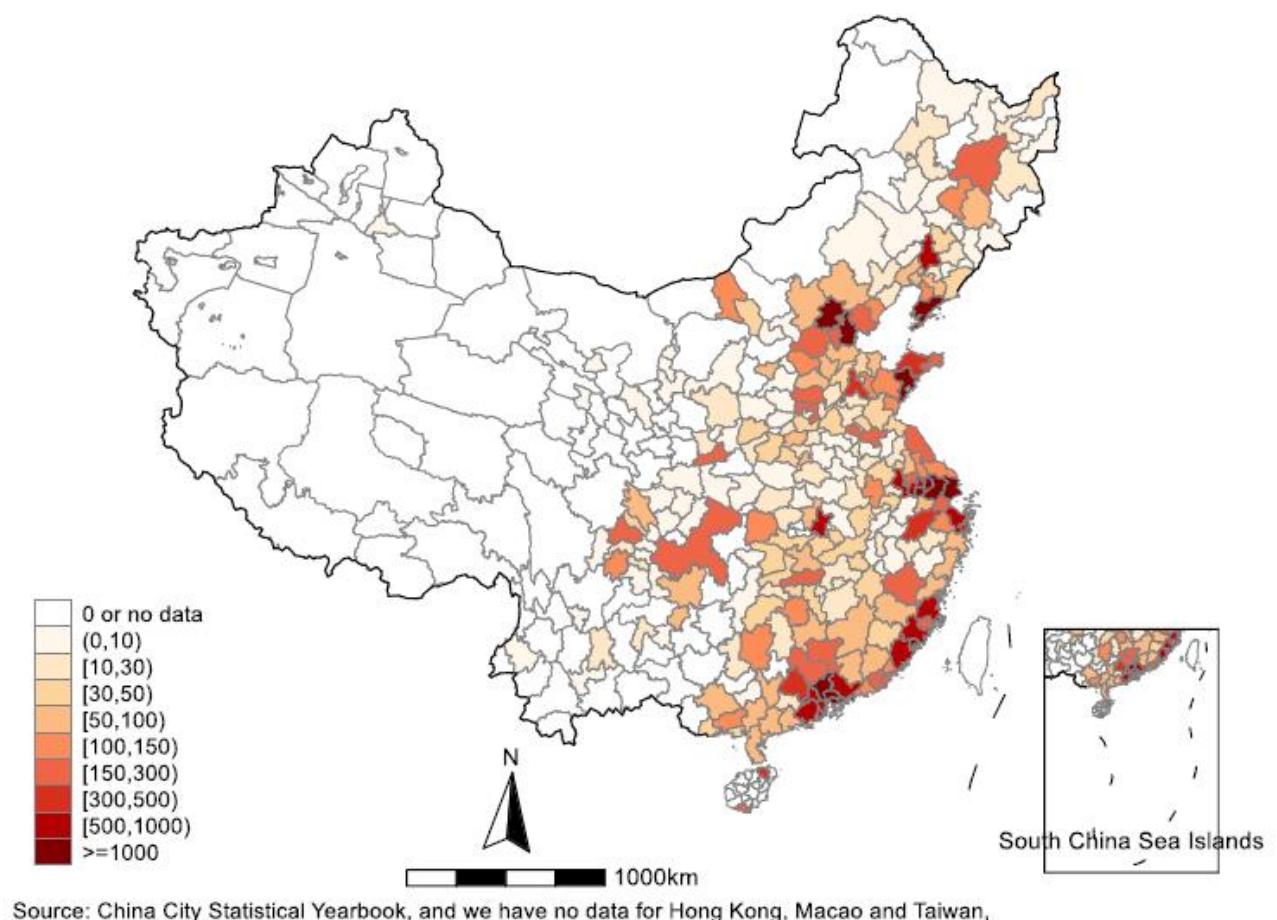

Figure 2. The location distribution of foreign capital actually utilized in China at Year 2000

Unit: Million US Dollars

In view of the reality, the international economics field has carried out a number of studies on the location determinants of FDI. According to the literature, this paper systematically summary the main determinants that affect the location choice of FDI. First, when multinational enterprises are engaged in FDI activities, in order to ensure long-term and smooth business, they usually give priority to examining the institutional factors of the host country, such as rules and regulations, investment environment, macroeconomic stability, and so on. Secondly, the main purpose of MNEs' FDI activities is the increase of capital and enterprise revenue, hence MNEs usually focus on the trade cost of production and sales in the host country, such as labor cost, tax rates, exchange rates, and whether the destination forms a strong industrial agglomeration, so that MNEs could be utilized the spillover effects of the industry. Thirdly, MNEs may use FDI activities for strategic purposes, so as to obtain specific objectives and resource, such as the domestic market of the host country, as well as natural resource reserves, even to achieve pollution transfer. At last, in addition to the determinants above, the impact of informal institutional factors on international investment activities has become increasingly prominent in recent years. For example, the cultural distance between the source country and the host country of FDI will largely affect the integration of multinational enterprises into the host country smoothly. At the same time, the interpersonal relationship between the source country and the host country will transmit information through social networks, and reduce the problem of incomplete information of MNEs to the host country, therefore cultural distance and social network are also important determinants in the location choice of FDI.

In the rest of the paper, section 2 analyses the impact of institution and investment environment on FDI location, section 3 presents the evidence that trade cost and industrial agglomeration are critical location determinants of FDI, section 4 concludes the importance of market scale and natural source for attracting FDI, section 5 introduces the effect of the two prominent determinants, cultural distance and social network, on the FDI location, section 6 makes a systematic summary for the paper and provides suggestions for further research.

\section{Institution and Investment Environment}

The institution of the host country not only directly determines the participation degree of FDI in the economic and social development of the host country, but also according to affect the investment environment and influence the investment preference of MNEs, due to the difference of investment environment is an important factor for the unbalanced distribution of FDI in the world (Cheng and Kwan, 2000). With the improvement of the institution and investment environment, it will increase the attractiveness of the host country to international 
capital, and promote the inflow of FDI. Compared with other economic factors, the influence of institution and investment environment on the location choice of FDI are more important (Buchanan et al., 2012; Kang and Jiang, 2012).

The risk of international investment often comes from the instability of institution and investment environment of the host country. Macroeconomic stability could be reducing the uncertainty faced by MNEs, therefore increasing the attractiveness of foreign direct investment. Arbatli (2011) finds that civil conflicts and political turbulence will have a significant negative impact on FDI inflows in emerging economies. Azzimonti (2019) presents similar evidence on the impact of trade policy partisanship index to the inflow of FDI in the United States. Through the impact of euro zone sovereignty and bank-related risks on FDI, Kellard et al. (2020) introduce that the sovereign risks of both the source country and the host country will affect the flow of FDI, and only the bank risk of the source country will affect the location choice of multinational enterprises. Blomström and Kokko (2000) show that the impact of regional integration agreements on the inflows of FDI mainly depends on the changes of trade environment and the location advantages of participating countries and industries. When regional integration agreements, trade liberalization and macroeconomic stability work together, it could have the most positive impact on the inflows of FDI. Furthermore, Blanc-Brude et al. (2014) introduce that economic distance has a positive effect on city-level policy to attract FDI in China. The literature above shows that the quality of institution and macroeconomic stability are important determinants on the location choice of FDI activities of MNEs.

In addition, some studies pointed out that government efficiency, supervision and incorruptibility are also play an important role in the inflow of FDI. Based on the analysis of the compensation model, Brouthers et al. (2008) find that the location choice of foreign direct investment is a tradeoff between the positive impact of market attractiveness and the negative impact of corruption. Although the larger market size can slightly reduce the adverse effects of corruption, this substitution effect will disappear rapidly with the improvement of the degree of corruption. From the perspective of enterprise life cycle, Contractor et al. (2020) find that countries with stronger contract enforcement and more effective compliance with international trade rules could attract more FDI. Through a sample of United States multinational enterprises investment in China from 1993 to 2001, Du et al. (2008a) provide evidence that FDI from United States is more inclined to entry the areas with better intellectual property protection, less government intervention, lower degree of corruption and better contract enforcement. The research above shows that the areas with better contract enforcement and property rights protection are more attractive to FDI, while the degree of government corruption will have a greater negative effect on the inflow of FDI.

\section{Trade Cost and Industrial Agglomeration}

As the carrier of international capital flows, the pursuit of capital accumulation is one of the main purposes of FDI activities. The lower trade cost could reduce production cost and obtain more profits for multinational enterprises, and the externality effect caused by industrial agglomeration will improve the productivity and market competitiveness of multinational enterprises. Therefore, trade cost and industrial agglomeration of the host country are also important determinants for multinational enterprises to make a decision for their destination when they wonder invest abroad.

In fact, MNEs could choose to entry the host country for production and operation in the form of FDI, but also choose to produce in the source country and export to the host country, or choose to invest through foreign portfolio investment (FPI) and other ways. International capital decides to invest in FDI rather than other forms, that means FDI has comparative advantages over other investment methods. Helpman et al. (2004) make use of the difference between enterprise productivity and production cost, explain why the enterprises with the highest productivity usually choose horizontal foreign direct investment for production and sales, while the enterprises with lower productivity choose to export and supplying the domestic market, the enterprises with the lowest productivity could only limit their business scope locally, because the fixed cost of export is lower and the variable cost is higher. It is opposite to FDI, therefore only the enterprises with highest productivity could undertake higher fixed cost and gain variable cost advantage. Goldstein and Razin (2006) compare FDI and FPI investment and find that capital owners invest in the form of FDI enables to understand the details and operating conditions of the target company clearly, and the information advantage is reflected in higher resale prices, which explains why international capital is more likely to entry the developing countries in the form of FDI, while FPI is more common used in the investment to developed countries.

Meanwhile, other studies show that trade cost is an important determinant in the entry mode of international capital and the location choice of FDI (Bernard et al.,2007). In general, the level of trade cost is influenced by 
geographical distance, production costs, tax rate, exchange rate fluctuations and other factors. Based on the knowledge-capital model, Carr et al. (2001) analyze the different motivation of horizontal and vertical FDI. In the former MNEs wants to bring products close to consumers to avoid excessive trade costs, and the final products or services are no different from those produced by domestic enterprises, while in the latter MNEs transfers part of the production abroad, due to factor prices or market scale. If the R\&D and production are carried out in different countries according to the level of skills and labor costs, the final products produced by enterprises in different countries are not the same. Fan et al. (2018) find that the increase in the minimum wage could explain the $32.3 \%$ increase in China's FDI in the period of 2001-2012, and this feature was stronger in foreign-funded enterprises, labor-intensive enterprises, coastal enterprises and productive FDI projects, which reflecting that rising labor costs in the source country of FDI is an important motivation for enterprises to invest abroad.

Blonigen (2005) highlights the role of taxation and exchange rate on the location choice of MNEs. Hines (1996) finds that foreign investors in countries with tax credits are more likely to invest in areas with higher tax rates in the United States, while investors who do not have such policy treatment usually choose to avoid high-tax areas, and FDI inflows increase average 7\%-9\% for $1 \%$ reduction in tax rates. The fluctuations of exchange rate will change enterprises' capital cost of internal financing and external borrowing of host countries. Froot and Stein (1991) study the relationship between exchange rate and FDI under the imperfect capital market model, and find that the appreciation of domestic currency increases the wealth growth of domestic enterprises, and provide more low-cost capital, thus increase foreign investment in devalued countries. Blonigen (1997) finds that the depreciation of the US dollar made Japan more likely to merge with American companies. Shi (2019) presents a similar conclusion from the macro model which including vertical FDI and exchange rate fluctuations in an open economy.

New economic geography emphasizes the realization of the effect of scale economies (Krugman,1999), in the context of professional division, it promotes local competitiveness of MNEs through the spillover effects brought by industrial agglomeration. Campos and Kinoshita (2003) find evidence that institutions, trade openness and industrial agglomeration are the three key factors affecting the entry of foreign investment in the economies of transition. Based on the cross-border investment experience of American manufacturing in the 1980s, Wheeler and Mody (1992) argue that although the government can attract foreign direct investment through taxes and other short-term incentives, while the effect is limited and high-cost. It is unnecessary for countries with good infrastructure, professional input suppliers and a growing market to join in the location competition. The key of attracting FDI is whether the local agglomeration economy could have enough influence. Empirical studies also show that the FDI elasticity of agglomeration effect to the same source country is about 0.11-0.15 (Bobonis and Shatz,2007). Majocchi and Presutti (2009) analyze the geographical distribution of foreign-funded enterprises in Italian manufacturing, and find that the impact of entrepreneurial culture and social capital on the investment choice of multinational enterprises is not stable, but the role of agglomeration economy is always significant. Using Swiss data, Brülhart et al. (2012) find that enterprises with higher degree of industry agglomeration are much less sensitive to differences in corporate tax burden than those with lower degree of industry agglomeration, which reflecting that the agglomeration effect not only affects the location choice of multinational enterprises, but also reduces the sensitivity of high tax rates.

From the experience of FDI flow into China, industrial agglomeration can also explain the differences in the distribution of foreign direct investment effectively (Head and Ries,1996). Du et al. (2008b) use the data of American, European, Japanese and Korean FDI enterprises in China, verify that agglomeration economy and government institution have positive influence on the location choice of FDI. Higher horizontal and vertical agglomeration and better regional system can promote the inflow of FDI. At the same time, the horizontal agglomeration of foreign enterprises could overcome the negative effects of institutional defects to some extent. Luo et al. (2008) find that policy incentives for the greater western development strategy and industrial agglomeration, rather than traditional factors such as natural resource and labor costs, are the main reasons for the inflow of FDI into China's inland areas. After measuring the agglomeration degree through a variety of indicators, Chen (2009) argues that urbanization, foreign capital agglomeration and industrial diversity have a significant impact on the location choice of FDI in China.

From the above research, the advantage on trade cost and industrial agglomeration of the host country can provide multinational enterprises with lower variable production costs, and take the spillover effects brought by enterprise agglomeration, thus enhancing the attractiveness of FDI inflow. 


\section{Market Scale and Natural Source}

Owing to the limited market scale of the source country is, or the inflating demand of economic development for natural resource, seeking a large market overseas and abundant supply of natural resource is also a common reason for multinational enterprises to carry out foreign direct investment activities. Blonigen et al. (2007) use the sample of OECD countries, and find that although geographical distance is an objective factor of limiting FDI inflow, the establishment of export platforms to occupy the market is the important reason for the flow of FDI from the United States to Europe. A similar phenomenon also occurs in the FDI flowing into China. In the study of Wei (2005), he points out that the reason why China receives more FDI from OECD countries than India, which is China has a larger domestic market and has a closer international trade relationship with OECD countries.

In addition, the natural resource of the host country is also an important reason to attract FDI. The natural resource of the host country can not only increase the inflow of FDI, but also change the structure of foreign direct investment. Campos and Kinoshita (2003) observe that the conditions of abundant natural resource had a particularly significant impact on the FDI inflow of former Soviet Union countries. In the research of Asiedu (2006), compared with the policy and institutional factors of the host country, the market size and natural resource have more significant influence on the inflow of FDI in Africa. Poelhekke and Ploeg (2013) observe the impact of newly discovered oil resource on subsequent FDI flows in resource countries, and find that the discovery of new resource leads to a significant decline in non-resource FDI inflows to host countries.

The natural resource above mainly includes mineral, petroleum and other physical natural resource. However, the environmental resource of the host country may also be one of the purposes for FDI activities of multinational enterprises. For example, due to the strict environmental protection standards of FDI source countries, multinational enterprises may transfer part of high-polluting production activities to the developing countries with lax environmental protection, to avoid environmental regulations and reduce production costs, which is the so-called pollution paradise hypothesis (Copeland and Taylor, 1994). In the existing studies, it is often taken as the side evidence of pollution transfer, according to the phenomenon that reduction of FDI inflow as the intensity of environmental regulation and the increase of the emission cost in the host country, or multinational enterprises tend to entry the regions with loose environmental regulation and weak environmental policies (Chichilnisky, 1994; Keller and Levinson, 2002; Kellenberg, 2009). Combined with China's experience, foreign direct investment plays a double-edged sword role, it promotes economic growth, labor productivity improvement and technological innovation, while it also leads to the increase of urban pollution emissions (Wang et al., 2013). At contrast, some studies find that FDI is more likely to choose the regions with transparent and stable environmental regulation, and multinational enterprises prefer to use clean energy and technology, which effectively improves the local environmental quality (Eskeland and Harrison, 2003; Kirkpatrick and Shimamoto, 2008; Albulescu et al., 2019; Hille et al., 2019), we do not discuss here further.

According to the above research, the market size of the host country is attractive for multinational enterprises to transfer part of the production to the host country, so as to provide more convenient products and services for the local enterprises and residents. The affluence of natural resource also has a positive effect on the inflow of resource FDI, while it will cause a crowding out effect on non-resource FDI, which may affect the industrial structure and economic growth of the host country.

\section{Cultural Distance and Social Network}

The increase in management costs caused by the increasing physical and cultural distance is also an important reason for the decrease in international investment of multinational enterprises (Blonigen and Piger, 2014; Blonigen et al., 2019). With the development of transportation facilities and communication technology, the geographical distance between the source country and host country is no longer the main determinant in FDI location decision, while the impact of cultural differences on FDI inflow and the entry mode of multinational enterprises has become increasingly prominent. Li et al. (2019) consider that compared to smaller, newer and non-state-owned enterprises, larger, older and state-owned enterprises in China usually own more resource, state-own enterprises pay less attention in the geographic distance which may lead to higher operating costs in the FDI activities, but they are poor to overcome big cultural differences due to lacking environmental adaptation ability. They use the data of 2001-2013 China's OFDI proves the hypothesis, and find that state-owned enterprises may pay more attention to cultural factors in the international investment. Du et al. (2012) use the data of foreign enterprises from six major source countries of FDI in China, and find that the larger the cultural distance between the source country and China, multinational enterprises are more likely to avoid the regions with poor economic system when choosing the location of international investment, and it was more obvious 
when the enterprises were wholly foreign-owned.

Since international investment is faced with incomplete information and uncertainty, the existence of social network could increase the access to acquire information for investors, which could reduce the potential risks of foreign direct investment effectively, thus improve the willingness of FDI activities of multinational enterprises. Therefore, social network will also a important determinant of FDI location choice. Tan and Meyer (2011) find that the same source country of FDI tend to have more effective information exchange between investors, thus it is better to reduce negative effects which is brought by uncertainty. According to the FDI information of Vietnam, they find that when the institutional environment is worse and dependence of FDI in the local economy is greater, it is more likely to result in the enterprises come from the same source country gathered together, rather than the enterprise come from the same industry. Buch et al. (2006) use the data of German immigrants and find that the region where the immigrants come from the same country usually have higher FDI inflows. Gao (2003) find that the existence of Chinese social network significantly promoted the foreign direct investment in the source countries to China, through the proportion of Chinese population in the source countries of FDI. All the above studies verify the positive role of social networks in attracting FDI inflows.

\section{Conclusion}

Based on the summary of existing literature, this paper classifies the main determinants on FDI location choice of MNEs into four aspects, which are institution and investment environment, trade cost and industrial agglomeration, market size and natural resource, cultural distance and social network. First, in order to successfully carry out production and operation activities, multinational enterprises usually investigate the institution design and investment environment of the host country at the macro level, so as to reduce possible systemic risks such as political instability and sovereign crisis. Secondly, in order to reduce the trade cost with the host country, and take the productivity improvement brought by agglomeration effect, multinational enterprises prefer the areas with lower trade costs and higher degree of industrial agglomeration. Thirdly, for strategic purposes, multinational enterprises usually prefer the host countries with large markets and rich natural resource, while in the pursuit of natural resource by FDI activities, which may take a crowding-out effect on non-resource FDI. Finally, when the factors at above are relatively close, the cultural distance between the source country and host country of FDI has gradually become an important determinant on MNCs' location choice. The closer the cultural distance is, the less uncertainty the MNCs will face. When faced with the risks caused by incomplete information, the social network between the source country and the host country will increase the channel to get information for multinational enterprises, which could reduce the potential risk in the international investment.

Judging from the main content of this paper, when promoting opening up to the world, countries should continue to improve the institution quality and business environment, as well as the efficiency and integrity of governments, reduce the operating costs of enterprises, promote industrial agglomeration, increase household consumption with economic growth as the driving force, enforce cultural exchanges with the world, strengthen exchanges with other countries, to attract FDI and other types of investment, and promote the country's economic growth and social development better.

According to the United Nations Conference of Trade and Development report, due to the COVID-19 in 2020, global FDI activity has dropped by $42 \%$ compared with the same period last year, Predictably, it will have a long-term impact on international economic activities, including FDI. At the same time, countries' position in the global value chain may also reshape as a result of the impact of the epidemic. It is valuable to pay attention to the impact of COVID-19 on the real economy and the expected changes to enterprises and residents, it is also one direction of our following research.

\section{References}

Albulescu, C. T., Tiwari, A. K., Yoon, S., \& Kang, S. H. (2019). FDI, Income, and Environmental Pollution in Latin America: Replication and Extension Using Panel Quantiles Regression Analysis. Energy Economics, 84, 104504. https://doi.org/10.1016/j.eneco.2019.104504

Arbatli, E. C. (2011). Economic Policies and FDI Inflows to Emerging Market Economies. IMF Working Paper, No.11/192. https://doi.org/10.5089/9781462306251.001

Asiedu, E. (2006). Foreign Direct Investment in Africa: The Role of Natural Resources, Market Size, Government Policy, Institutions and Political Instability. World Economy, 29(1), 63-77. https://doi.org/10.1111/j.1467-9701.2006.00758.x

Azzimonti, M. (2019). Does Partisan Conflict Deter FDI Inflows to the US? Journal of International Economics, 
120, 162-178. https://doi.org/10.1016/j.jinteco.2019.06.001

Bernard, A. B., Redding, S. J., \& Schott, P. K. (2007). Comparative Advantage and Heterogeneous Firms. Review of Economic Studies, 74(1), 31-66. https://doi.org/10.1111/j.1467-937X.2007.00413.x

Blanc-Brude, F., Cookson G., Piesse J., \& Strange, R. (2014). The FDI Location Decision: Distance and the Effects of Spatial Dependence. International Business Review, 23, 797-810. https://doi.org/10.1016/j.ibusrev.2013.12.002

Blomström, M., \& Kokko, A. (2000). Regional Integration and Foreign Direct Investment. Oxford University Press. In Dunning, John (Eds.), Regions, Globalization and the Knowledge-Based Economy.

Blonigen, B. A. (1997). Firm-Specific Assets and the Link between Exchange Rates and Foreign Direct Investment. American Economic Review, 87(3), 447-465.

Blonigen, B. A. (2005). A Review of the Empirical Literature on FDI Determinants. Atlantic Economic Journal, 33(4), 383-403. https://doi.org/10.1007/s11293-005-2868-9

Blonigen, B. A., \& Piger, J. (2014). Determinants of Foreign Direct Investment. Canadian Journal of Economics, 47(3), 775-812. https://doi.org/10.1111/caje.12091

Blonigen, B. A., Cristea A. D., \& Lee, D. (2019). Evidence for the Effect of Monitoring Costs on Foreign Direct Investment. NBER Working Paper, No.25933. https://doi.org/10.3386/w25933

Blonigen, B. A., Davies, R. B., Waddell, G. R., \& Naughton, H. T. (2007). FDI in Space: Spatial Autoregressive Relationships in Foreign Direct Investment. European Economic Review, 51(5), 1303-1325. https://doi.org/10.1016/j.euroecorev.2006.08.006

Bobonis, G. J., \& Shatz, H. J. (2007). Agglomeration, Adjustment, and State Policies in the Location of Foreign Direct Investment in the United States. Review of Economics and Statistics, 89(1), 30-43. https://doi.org/10.1162/rest.89.1.30

Brouthers, L. E., Gao Y., \& McNicol, J. P. (2008). Corruption and Market Attractiveness Influences on Different Types of FDI. Strategic Management Journal, 29(6), 673-680. https://doi.org/10.1002/smj.669

Brülhart, M., Jametti, M., \& Schmidheiny, K. (2012). Do Agglomeration Economics Reduce the Sensitivity of Firm Location to Tax Differentials. Economic Journal, 122(563), 1069-1093. https://doi.org/10.1111/j.1468-0297.2012.02511.x

Buch, C. M., Kleinert, J., \& Toubal, F. (2006). Where Enterprises Lead, People Follow? Links between Migration and FDI in Germany. European Economic Review, 50(8), 2017-2036. https://doi.org/10.1016/j.euroecorev.2005.11.002

Buchanan, B. G., Le, Q. V., \& Rishi, M. (2012). Foreign Direct Investment and Institutional Quality: Some Empirical Evidence. International Review of Financial Analysis, 21, 81-89. https://doi.org/10.1016/j.irfa.2011.10.001

Campos, N. F., \& Kinoshita, Y. (2003). Why Does FDI Go Where it Goes? New Evidence from the Transition Economies. IMF Working Paper, No. 03/228. https://doi.org/10.5089/9781451875461.001

Carr, D. L., Markusen, J. R., \& Maskus, K. E. (2001). Estimating the Knowledge-Capital Model of the Multinational Enterprise. American Economic Review, 91(3), 693-708. https://doi.org/10.1257/aer.91.3.693

Chen, Y. (2009). Agglomeration and Location of Foreign Direct Investment: The Case of China. China Economic Review, 20(3), 549-557. https://doi.org/10.1016/j.chieco.2009.03.005

Cheng, L. K., \& Kwan, Y. K. (2000). What Are the Determinants of the Location of Foreign Direct Investment? The Chinese Experience. Journal of International Economics, 51(2), 379-400. https://doi.org/10.1016/S0022-1996(99)00032-X

Chichilnisky, G. (1994). North-South Trade and the Global Environment. American Economic Review, 84(4), 851-874.

Contractor, F. J., Dangol, R., Nuruzzaman, N., \& Raghunath, S. (2020). How Do Country Regulations and Business Environment Impact Foreign Direct Investment (FDI) Inflows? International Business Review, 29(2), 101640. https://doi.org/10.1016/j.ibusrev.2019.101640

Copeland, B. R., \& Taylor, M. S. (1994). North-South Trade and the Environment. Quarterly Journal of Economics, 109(3), 755-787. https://doi.org/10.2307/2118421 
Du, J., Lu, Y., \& Tao, Z. (2008a). Economic Institutions and FDI Location Choice: Evidence from US Multinationals in China. Journal of Comparative Economics, 36(3), 412-429. https://doi.org/10.1016/j.jce.2008.04.004

Du, J., Lu, Y., \& Tao, Z. (2008b). FDI Location Choice: Agglomeration vs Institutions. International Journal of Finance and Economics, 13, 92-107. https://doi.org/10.1002/ijfe.348

Du, J., Lu, Y., \& Tao, Z. (2012) Institutions and FDI Location Choice: The Role of Culture Distances. Journal of Asian Economics, 23(3), 210-223. https://doi.org/10.1016/j.asieco.2010.11.008

Eskeland, G. S., \& Harrison, A. E. (2003). Moving to Greener Pastures? Multinationals and the Pollution Haven Hypothesis. Journal of Development Economics, 70(1), 1-23. https://doi.org/10.1016/S0304-3878(02)00084-6

Fan, H., Lin, F., \& Tang, L. (2018). Minimum Wage and Outward FDI from China. Journal of Development Economics, 135, 1-19. https://doi.org/10.1016/j.jdeveco.2018.06.013

Feenstra, R. C., \& Hanson, G. H. (1997). Foreign Direct Investment and Relative Wages: Evidence from Mexico's Maquiladoras. Journal of International Economics, 42(3-4), 371-393. https://doi.org/10.1016/S0022-1996(96)01475-4

Froot, K. A., \& Stein, J. C. (1991). Exchange Rates and Foreign Direct Investment: An Imperfect Capital Markets Approach. Quarterly Journal of Economics, 427(4), 1191-1217. https://doi.org/10.2307/2937961

Gao, T. (2003). Ethnic Chinese Networks and International Investment: Evidence from Inward FDI in China. Journal of Asian Economics, 14(4), 611-629. https://doi.org/10.1016/S1049-0078(03)00098-8

Goldstein, I., \& Razin, A. (2006). An Information-Based Trade off between Foreign Direct Investment and Foreign Portfolio Investment. Journal of International Economics, 70(1), 271-295. https://doi.org/10.1016/j.jinteco.2005.12.002

Head, K., \& Ries, J. (1996). Inter-City Competition for Foreign Investment: Static and Dynamic Effects of China's Incentive Areas. Journal of Urban Economics, 40, 38-60. https://doi.org/10.1006/juec.1996.0022

Helpman, E., Melitz, M. J., \& Yeaple, S. R. (2004). Export versus FDI with Heterogeneous Firms. American Economic Review, 94(1), 300-316. https://doi.org/10.1257/000282804322970814

Hille, E., Shahbaz M., \& Moosa, I. (2019). The Impact of FDI on Regional Air Pollution in the Republic of Korea: A Way Ahead to Achieve the Green Growth Strategy? Energy Economics, 81, 308-326. https://doi.org/10.1016/j.eneco.2019.04.004

Hines, J. R. Jr. (1996). Altered States: Taxes and the Location of Foreign Direct Investment in America," American Economic Review, 86(5), 1076-1094.

Kang, Y., \& Jiang, F. (2012). FDI Location Choice of Chinese Multinationals in East and Southeast Asia: Traditional Economic Factors and Institutional Perspective. Journal of World Business, 47(1), 45-53. https://doi.org/10.1016/j.jwb.2010.10.019

Kellard, N. M., Kontonikas, A., Lamla, M. J., Maiani, S., \& Wood, G. (2020). Risk, Financial Stability and FDI. Journal of International Money and Finance, 102232. https://doi.org/10.1016/j.jimonfin.2020.102232

Kellenberg, D. K. (2009). An Empirical Investigation of the Pollution Haven Effect with Strategic Environment and Trade Policy. Journal of International Economics, 78(2), 242-255. https://doi.org/10.1016/j.jinteco.2009.04.004

Keller, W., \& Levinson, A. (2002). Pollution Abatement Costs and Foreign Direct Investment Inflows to U.S. States. Review of Economics and Statistics, 84(4), 691-703. https://doi.org/10.1162/003465302760556503

Kirkpatrick, C., \& Shimamoto, K. (2008). The Effect of Environmental Regulation on the Locational Choice of Japanese Foreign Direct Investment. Applied Economics, 40(11), 1399-1409. https://doi.org/10.1080/00036840600794330

Krugman, P. R. (1999). Increasing Return and Economic Geography. Journal of Political Economy, 99, 483-499. https://doi.org/10.1086/261763

Li, Y., Zhang, Y. A., \& Shi, W. (2019). Navigating Geographic and Cultural Distances in International Expansion: The Paradox of Firm Size, Age, and Ownership. Strategic Management Journal, 41(5), 1-29. https://doi.org/10.1002/smj.3098

Lipsey, R. E., \& SjÖHolm, F. (2004). Foreign Direct Investment, Education and Wages in Indonesian 
Manufacturing. Journal of Development Economics, 73(1), 415-422. https://doi.org/10.1016/j.jdeveco.2002.12.004

Luo, L., Brennan, L., Liu, C., \& Luo, Y. (2008). Factors Influencing FDI Location Choice in China's Inland Areas. China \& World Economy, 16(2), 93-108. https://doi.org/10.1111/j.1749-124X.2008.00109.x

Majocchi, A., \& Presutti, M. (2009). Industrial Clusters, Entrepreneurial Culture and the Social Environment: The Effects on FDI Distribution. International Business Review, 18(1), 76-88. https://doi.org/10.1016/j.ibusrev.2008.12.001

Mišun, J., \& Tomšk, V. (2002). Does Foreign Direct Investment Crowd In or Crowd Out Domestic Investment? Eastern European Economics, 40(2), 38-56. https://doi.org/10.1080/00128775.2002.11041015

Poelhekke, S., \& Ploeg, F. (2013). Do Natural Resources Attract Nonresource FDI? Review of Economics and Statistics, 95(3), 1046-1065. https://doi.org/10.1162/REST_a_00292

Shi, J. (2019). Vertical FDI and Exchange Rates Over the Business Cycle: The Welfare Implications of Openness to FDI. Journal of Development Economics, 138, 274-293. https://doi.org/10.1016/j.jdeveco.2019.01.004

Tan, D., \& Meyer, K. E. (2011). Country-of-origin and Industry FDI Agglomeration of Foreign Investors in an Emerging Economy. Journal of International Business Studies, 42(4), 504-520. https://doi.org/10.1057/jibs.2011.4

Wang, D. T., Gu, F. F., Tse, D. K., \& Yim, C. K. (2013). When Does FDI Matter? The Roles of Local Institutions and Ethnic Origins of FDI. International Business Review, 22(2), 450-465. https://doi.org/10.1016/j.ibusrev.2012.06.003

Wei, W. (2005). China and India: Any Difference in Their FDI Performances? Journal of Asian Economics, 16(4). 719-736. https://doi.org/10.1016/j.asieco.2005.06.004

Wheeler, D., \& Mody, A. (1992). International Investment Location Decisions: The Case of U.S. Firms. Journal of International Economics, 33(1), 57-76. https://doi.org/10.1016/0022-1996(92)90050-T

\section{Copyrights}

Copyright for this article is retained by the author(s), with first publication rights granted to the journal.

This is an open-access article distributed under the terms and conditions of the Creative Commons Attribution license (http://creativecommons.org/licenses/by/4.0/). 